Largest stock of

\section{RUSSIAN BOOKS}

in North America

RECORDS

HANDICRAFT

PERIODICALS

SUBSCRIPTIONS

DICTIONARIES

TEXTBOOKS

Mail your order for

FREE CATALOGUES

today

VICTOR KAMKIN, Inc.

Publishers, Booksellers, Importers 1410 Columbia Road, N.W.

Washington, D.C. 20009

North 7-0690
AN ANNOTATED

BIBLIOGRAPHY

Books and articles on Modern Language

Teaching 1946-1967

JANET O. ROBINSON

Fifteen hundred selected references on all aspects of modern language teaching. $\$ 2.75$

\section{SET AND RELATIONS \\ IN PHONOLOGY}

An Axiomatic

Approach to the

Description of

Speech

J. W. F. MULDER

This work aims at a similar exactitude in linguistics as is common to the physical sciences. It attempts to follow closely the axiomatic methods used in those sciences; precision of statement is achieved by applying such principles as mathematical logic, set theory and relation theory. $\$ 9.50$

\section{OXFORD}




\section{A Dictionary of Canadianisms on Historical Principles}

Prepared for W. J. Gage Limited by the Lexicographical Centre for Canadian English, University of Victoria, British Columbia

Editorial Board: Walter S. Avis, Editor-in-Chief; Charles Crate; Patrick Drysdale; Douglas Leechman; Matthew H. Scargill

Over 10,000 entries 960 pages list price $\$ 25.00$ Now available from bookstores or direct from the publisher

A long-awaited work of original linguistic scholarship, published as part of the Dictionary of Canadian English series

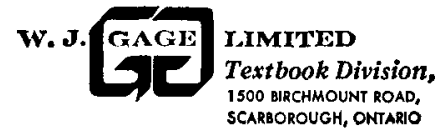




\section{The Canadian \\ Linguistic Association}

wishes to announce that

its 1969 meeting will be held at

York University, Toronto,

on June 11, 12, and 13.

Further particulars will be

publicized when they are available. 